\title{
STUDY OF THE PECULIARITIES OF THE TRANSFORMATION OF THE GROUND COVER OF SRIVASHSHYA BY UNDER THE INFLUENCE OF NATURAL AND ANTHROPOGENIC FACTORS (ON THE EXAMPLE OF THE NOVOTROITSKY REGION AND THE AZOV- SYVASH NATIONAL NATURAL PARK)
}

\author{
I.S. Polova, assistant \\ Email: polevayaira95@gmail.com \\ S.V. Fokina, assistant \\ Email: sfokina19862013@gmail.com
}

State higher education institution «Kherson state agricultural university»

Abstract. The article deals with the peculiarities of the transformation of the Srivashshya soil in an example of a comparative analysis of soil transformation in the Novotroitsky region and the Azov-Sivash National Natural Park under the influence of natural and anthropogenic factors.

Soils of the Northern Pryvashshya, namely Novotroitskiy district, undergo significant transformations caused by anthropogenic activity, quickly lose their positive properties when irrational agricultural use.

Long-term use of soils in arable land and, in particular, the use of reclamation measures, predetermine the existence of soil processes that differ from those existing in the natural environment and are currently poorly understood. In today's conditions of use of land resources, precise information is needed on the features of the qualitative state of saline soils for monitoring and rational agricultural use, in connection with which the issues studied are of particular scientific and practical significance.

On the basis of the comparative analysis, the differences between soils of agricultural use and soils, which do not undergo anthropogenic influence, that is, are in the natural state within the protected areas, are determined. It is proved that the soils of the protected area in comparison with the soil cover of Novotroitsky district, will not undergo significant anthropogenic influence. The territory of the 
Novotroitsky district is characterized by large scale devastation of agricultural land.

Key words: Azov-Syvash national natural park, soil cover, agro-transformed soils, reclamation, natural and anthropogenic factors.

\section{Topicality.}

The urgency of studying the peculiarities of soil transformation on the basis of comparative analysis of the soil cover of the Novotroitsky district and the AzovSivash National Natural Park is due to the fact that the soils of the studied region undergo significant transformations under the influence of anthropogenic activity. As a result, relevant degradation processes are becoming widespread in this area, such as: secondary irrigation salinization of soils, wind erosion, decrease in humus content, which affects the change of qualitative characteristics of the soil of the region, which directly leads to a decrease in the soil fertility of the investigated area.

Prolonged involvement of soils, which have solonoctane properties to arable land, and especially the use of meliorative measures, cause the appearance of soil processes that differ from those existing in the natural environment and at this stage of their development are not sufficiently studied. That is why, on the basis of comparison, we need to find out the existing differences between soils of agricultural use and soils that do not undergo anthropogenic influence (in the natural state) within the protected areas. It is also important to find out the causal relationships that cause changes in soil-forming processes.

\section{Analysis of recent research and publications.}

According to the definition of many soil scientists, soils having solonoctane properties belong to complex natural entities with a long history of genesis and evolution, but so far remain insufficiently studied.

The peculiarities of the development of the corresponding soils, under the influence of anthropogenic factors, were described in the works of S.P. SemenovaZabrodina, V.D.Muha, A.M.Mozeyk, M.P.Panova. 
In today's conditions, when the process of land reform is actively under way, precise information on the qualitative state of the soil for monitoring and compiling a system of rational agricultural use is needed, which is why the relevant issues acquire special scientific and practical significance.

Improving the quality of soil characteristics requires a more in-depth analysis of existing data and their use in further research.

The purpose of the study is to determine the patterns of changes in properties and the direction of evolution of the transformed soils of the Ssivashshya on the basis of a comparative analysis of the soil cover of the Novotroitsky region and the Azov-Sivash National Natural Park.

\section{Materials and methods of research.}

Used literary and online sources, as well as materials of their own research. In the course of the research, the method of field research was used to study the features of soil transformation as a result of the influence of various factors on the ground; the method of analysis, systematization and synthesis of literary sources for determining the conditions and processes of formation of the soil cover of the region of research, its dynamics; the cartographic method was used to create a mapping pattern for the distribution of soil types, vegetation cover within the Novotroitsky region; the comparative-geographic method is used to analyze the differences in the composition and fertility of irrigated and non-irrigated soils; The method of analysis of interconnections and interdependencies is used to analyze the influence of climatic conditions on the formation of soil composition and its fertility.

\section{Results of the research and their discussion.}

The explored area covers the southern part of the Black Sea Lowland, which in tectonically corresponds to the Black Sea Basin and is a steppe plain. On the coastal part there is a distribution of shallow bays and saline lagoons [2].

The geological and geomorphological structure of the territory of the Northern Prisivash is characterized by its location on the border of the ancient and young platforms. The features of the geological structure of the region of research 
are due to sedimentary rocks with a capacity up to $3000 \mathrm{~m}$ and lie on the Precambrian crystalline basement.

In the Quaternary period, the Prisivash subsoil was subjected to epyrogenic motions mainly of a negative sign, as a result of which this area was constantly flooded with the sea, resulting in the parent rock having saltinating properties. At this stage of development, slight elevations of individual sites are observed against the background of general epirogenetic subsidence. Disjunctive disturbances of the earth's crust and depleted phenomena in the territory of the Northern Prisivash are not observed [4].

The process of soil formation in the studied territory proceeds against the background of clearly expressed vertical zoning and depends on arid climatic conditions, salinity of soil-forming rocks and a very low level of natural drainage of the territory, which in turn led to the formation of dark chestnut, meadow chestnut sootlonceous soils, chestnut sootolenic soils and solonetines chestnut [6]. The presence of a large set of salt and saline soils, as well as semi-hydromorphic and hydromorphic soils complicate the structure of the soil cover of the investigated area (Fig. 1). 


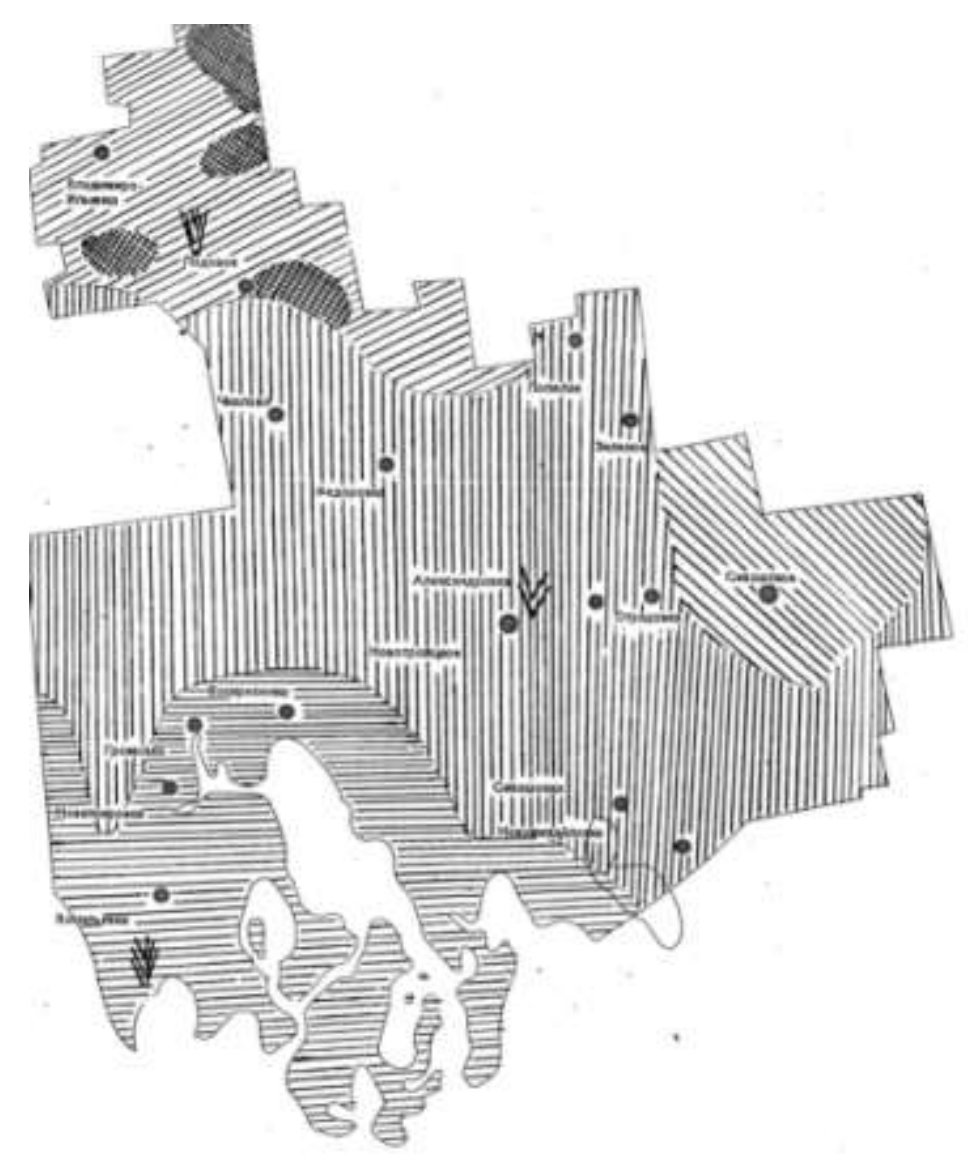

Fig. 1. Mapping of the soil of Novotroitsky district

QII - Chernozem south residual salt-soluble. Dark chestnut residual solonets.Meadow-chernozem and turf solodizyli gley soils and malt.

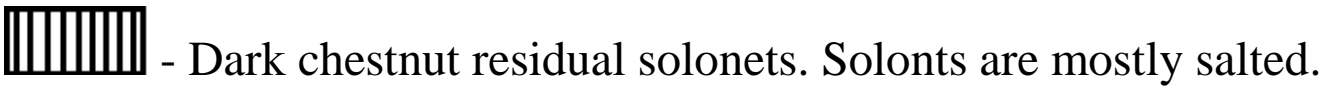

Ele - Chestnut Salt. Solonts are mostly salted.

NWV - Solonts are mostly salted. Meadow-chernozem and turf solodizyli gley soils and malt.

- Meadow-chernozem and turf solodizyli gley soils and malt.

Source: compiled by the author on the basis of [2].

Soil cover of Novotroitsky region undergoes significant transformations under the influence of anthropogenic factors, as a result, the spread of such degradation processes as secondary irrigation salinization of the soil, the spread of wind erosion, which leads to a decrease in the content of humus in the soil, so that the soil quickly lose its positive properties in the irrational agricultural use [5, 7]. 
The researches have established that the content of humus in the upper layer $(0-60 \mathrm{~cm})$ of soil, where the plowing plots and unplanned soils are applied, have not undergone significant changes. In the layer of soil directly used in arable land, humus content in planted and unplaced soils varies within 1,9-2,0\% (Table 1). It is observed its uniform distribution on the profile of the soil with its regular decrease with depth. Humus reserves in the upper layer $(0-60 \mathrm{~cm})$ of planted soils are slightly larger (123.4 t/ ha on the plantation at $116.9 \mathrm{t} /$ ha on the control) (Fig. 2).

1. Dynamics of the total content of humus $(\%)$ in the salinity of the chestnut territory of the Novotroitsky district

\begin{tabular}{|c|c|c|c|}
\hline \multirow{2}{*}{ Year } & Depth, & \multicolumn{2}{|c|}{ Version } \\
\cline { 2 - 4 } & centimeters & Plot & Control \\
\hline \multirow{3}{*}{2016} & $0-30$ & 1,7 & 2,0 \\
\cline { 2 - 4 } & $30-40$ & 1,6 & 1,6 \\
\cline { 2 - 4 } & $40-60$ & 1,4 & 1,0 \\
\hline \multirow{4}{*}{2017} & $0-30$ & 2,3 & 2,0 \\
\cline { 2 - 4 } & $30-40$ & 1,8 & 1,8 \\
\cline { 2 - 4 } & $40-60$ & 1,7 & 1,0 \\
\hline \multirow{4}{*}{2018} & $0-30$ & 2,2 & 2,0 \\
\cline { 2 - 4 } & $30-40$ & 1,9 & 1,7 \\
\cline { 2 - 4 } & $40-60$ & 1,7 & 1,0 \\
\hline
\end{tabular}

Source: compiled by the author on the basis of [6].

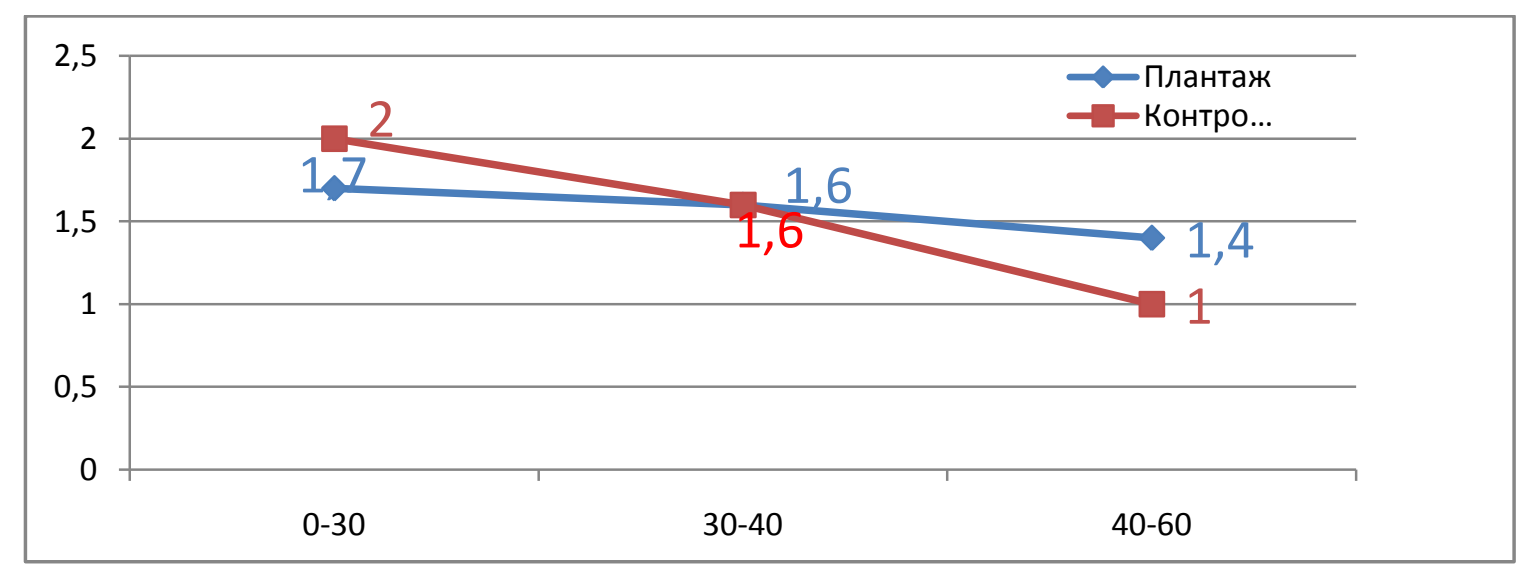

Fig. 2. Dynamics of the total content of humus in the solonets of chestnut territory of Novotroitsky region during 2018 
Source: own development of the author.

Azov-Sivash National Natural Park is a protected area under the protected steppes, where the soil cover along the Gulf of Sivash has a certain specificity associated with the conditions of formation [3]. Soils of the protected area in comparison with the soil cover of Novotroitsky district, will not undergo significant anthropogenic influence.

The territory of Novotroitsky district is characterized by large scale plowing of agricultural land. As a result of the sprouting of saline soils some changes occur in the morphological structure of their profile. Hollow-eluvial, eluvial and partially illuvial horizons are formed in saline soils. There is a decrease in the power of the illuvial horizon by $5-10 \mathrm{~cm}$. Annual annihilation leads to the spread of deflation processes and water erosion of the soil. the enhanced interaction of soils. Pesting of soils is accompanied by changes in their mechanical composition.

The use of plowing plowing and the use of reclamation measures leads to certain changes in the organization of the humus profile and the content of the humus itself in dark chestnut sootlon soils. When using the abovementioned methods of cultivating the soil, the upper part of the soil profile, having the maximum reserves of humus moves deeper, therefore, in the near future there is a decrease in the content of humus in the arable soil layer by $15-20 \%$. In the layers of the soil profile, located deeper $(30-60 \mathrm{~cm})$, there is an active process of increasing the organic matter by $40-80 \%$, compared with the same depth on unplanned soils.

In unplanned variants of solonetines of chestnut and dark chestnut soils, there is a process of reducing the content of mineral salts. The process is influenced by precipitation and meliorative measures, namely irrigation.

With the prolonged use of planted solonetz and the so-called mono-chestnut sootlonite soils, there is no restoration of the process of salinization during the study period, which is confirmed by the lack of a texture division of the soil profile on the eluvially illuvial horizon, and therefore confirms the continuation of the positive effect of reclamation plantation plowing [1]. 
The structure of the profile of the chestnut solonetz can be judged from the description of the section and the stationary study from 2017-2018 in the territory of the Prisivash region (Fig. 3).

In planted soil variants there is a uniform distribution of the game in the meliorated layer $(0-60 \mathrm{~cm})$, with the difference between the layer of soil that is involved in arable land and the layer of $40-60 \mathrm{~cm}$ is about $20 \%$, whereas in the unplanned analogues this difference rises to $40-50 \%$.
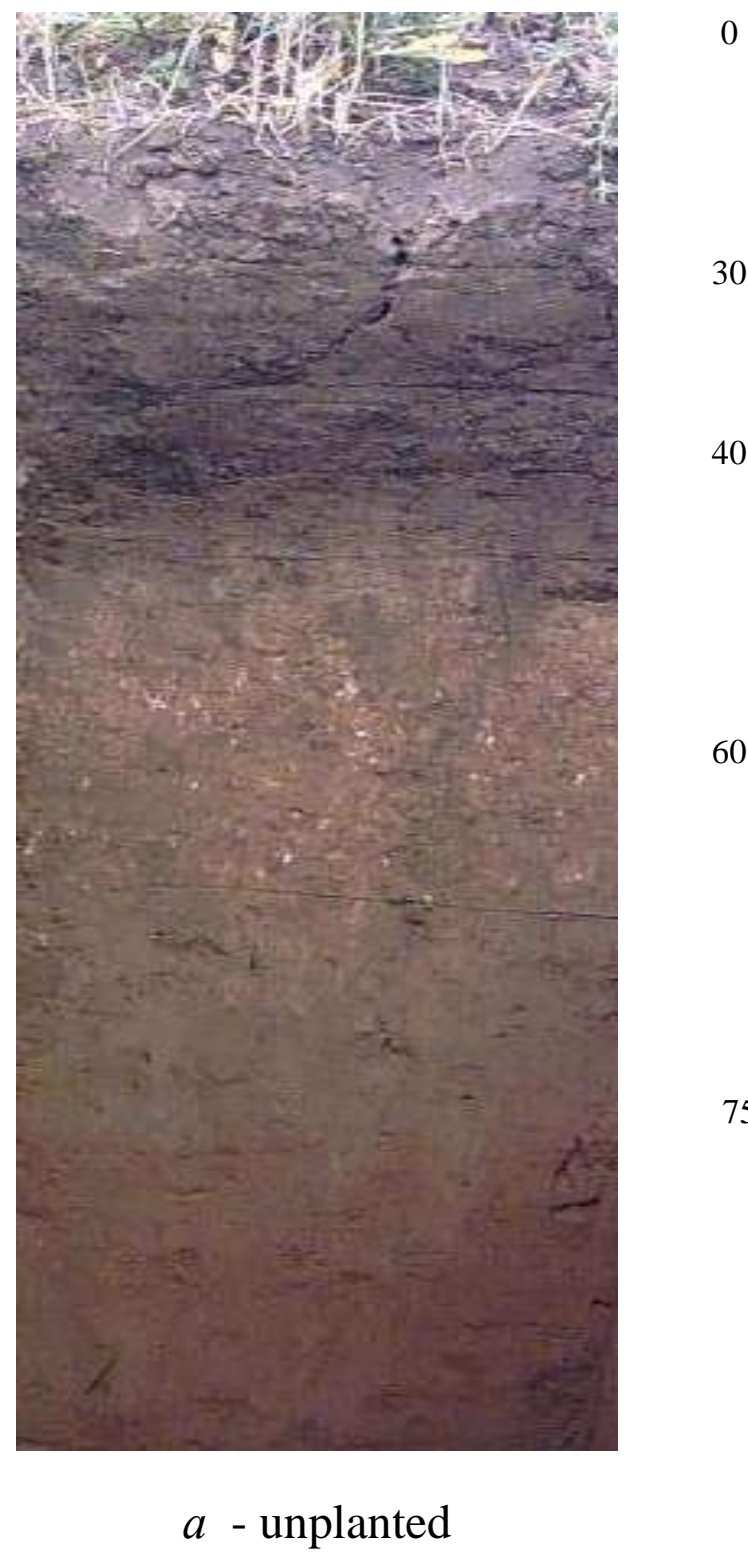

40

60

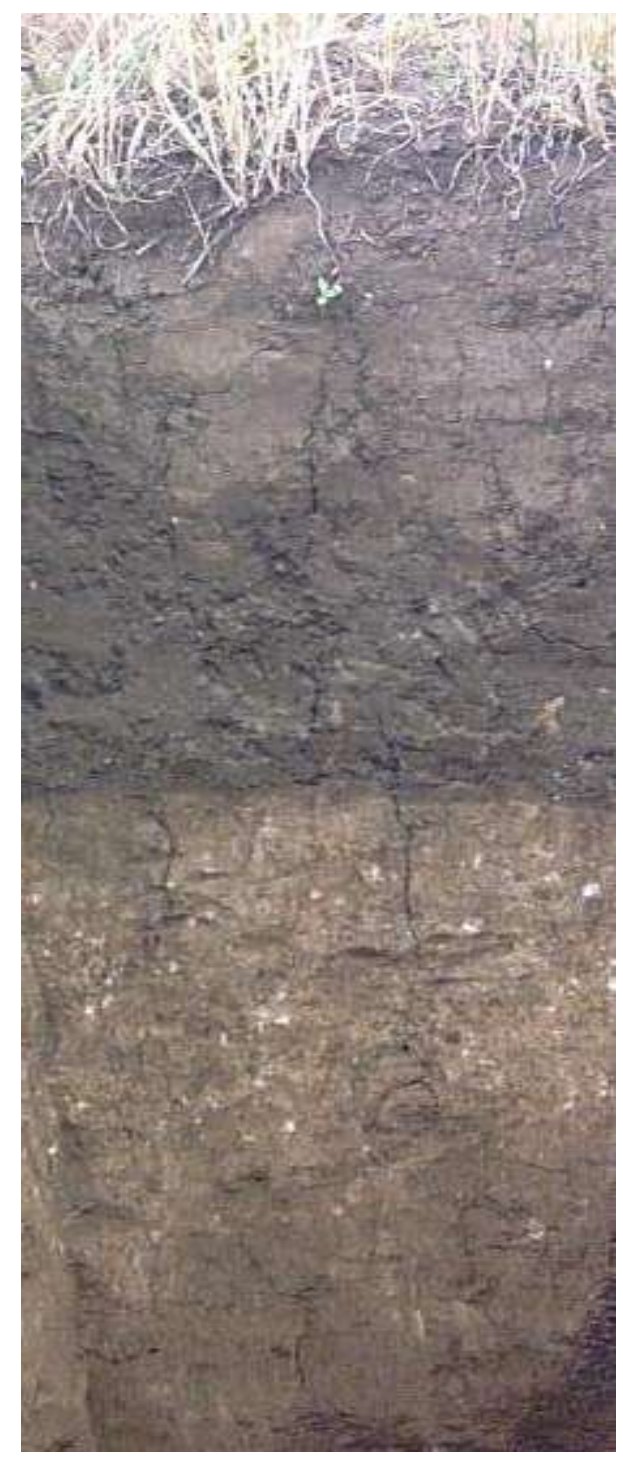

$\sigma$ - planted

Fig. 3. Structure of the profile of salt of chestnut deep-sunny-bellied lightflask on the territory of Novotroitsky district: a- unplanned; b- planted.

Source: author's photo. 
In saline soils, which are not involved in plowing plowing, the content of humus in the arable layer has not changed significantly. The content of humus in a layer of 30-40 cm increases due to the root parts of plants that ensure the flow of ash into the soil. The appropriate soil layer has optimal hydrothermal conditions, and is characterized by depression of mineralization processes. Due to an increase in the content of humus in a layer of $30-40 \mathrm{~cm}$, there is an increase in its reserves in the upper layer $(0-60 \mathrm{~cm})$ of unplanned solonetsoic soils.

Significant influence on the reclaimed layer causes the annual tillage of the soil after the reclamation period. As a result, there is a more even distribution of calcium carbonates, in the layer of soil, which is involved in arable land, the confirmation of which is a continuous boiling of $10 \%$ hydrochloric acid. The conducted researches have established that in the long-term aftereffects in the planted soils the cultivated arable layer is isolated, which under the influence of constant regular cultivation undergoes some changes and becomes uniform in structure and coloring. Below, in the soil profile, a subterranean layer $(30-40 \mathrm{~cm})$ forms, which also has a homogeneous structure, but somewhat denser in comparison to the upper layer of soil, with the absence of muddy fractions and the formation of solonetine horizons. A deeper part is the agro-transformed layer of soil $(40-60 \mathrm{~cm})$, which consists of fractions, which are canceled apart from each other not only by composition but also by the size of fragments of the original genetic horizons. Carbonate horizons are located below the agro-transformed layer, which were not involved in agricultural cultivation and, accordingly, have a natural structure $[7,8]$.

\section{Conclusions and perspectives}

Consequently, a comparative analysis of the current state of soil cover and research results, we can conclude the following:

In the natural state, dark-chestnut sootolithic soils are characterized by a clear division of the soil profile into the eluvial and illuvial horizons. Investigation of the morphological structure of the soil profile of the soototonic soils of the Novotroitsky region, which have been involved in arable land for a long time, 
showed that the virgin saline pancreatic profile changes somewhat, and if it is stored as a solonethic, then only in the part of solonets, provided that the depth of the plowing does not exceed the depth of the occurrence of the solonethic horizon itself . Meliorative plowing plowing leads to more significant transformations of the morphological structure of the soil profile. As a result, the mechanical destruction of the dense solonetsof horizon, the mixing of the eluvial, the illuvial and the transient horizons, the involvement of calcium carbonates from the earth's horizons below the arable layer of calcium, resulting in a significant increase in the profile of the saltinese soils. The ground cover of the Azov-Sivash National Natural Park undergoes changes only due to the influence of natural factors: there is a natural salinization and salinization of soils due to the geographical location of the territory, the tectonic, geological and geomorphological structure of the research area, as well as the climatic conditions of the territory concerned.

The transformation of the soil cover of the territory of the Novotroitsky region occurs both under the influence of natural and anthropogenic factors, and the transformation of the ground cover of the Azov-Sivash National Natural Park occurs mainly under the influence of natural factors. When attracting salt and dark chestnut soils of the Novotroitsky district to arable land and their long agricultural use, the use of meliorative measures (reclamation plowing and irrigation) caused some changes in qualitative soil characteristics, especially their salt composition. They undergo a positive anthropogenic transformation and lose most of those morphological features and signs, according to which in the virgin state they were identified as their own solonets or solonethous soils, which in turn determines plowing plowing as a positive measure of soil optimization in the Novotroitsky region. 


\section{References}

1. Baliuk , S.A., Novikova, H.V., Havrylovych, N.Yu. (2009). Vykorystannia solontsevykh gruntiv Ukrainy [The use of soot-rich soils in Ukraine]. Visnyk ahrarnoi nauky. Science, 12-15.

2. Pylypenko, I. O., Malchykova, D. S., Yermakova, S. L., Rudenko, M. M. ta in.(2007). Heohrafiia Khersonshchyny [Geography of Kherson region].Navch. posibnyk.Kherson, PP Vyshemyrskyi V.S. 221.

3. Davydov, O.V., Roskos, N.O., Roskos, O.M. (2013). Zahalni osoblyvosti poshyrennia roslynnosti na berezi zatoky Syvash, Azovske more [General features of the spread of vegetation on the shore of the Gulf of Sivash, the Sea of Azov]. Visnyk ONU, Ser. Heohrafichni ta heolohichni nauky, 18/3(10), 57-64.

4. Davydov, O.V., Kriuchkova, T.M., Roskos, O.M. (2008). Suchasnyi hidrolohichnyi rezhym zatoky Syvash yak dominuiuchyi faktor rozvytku berehovoi smuhy [The modern hydrological regime of the Sivash Bay as a dominant factor in the development of the coastal strip]. Visnyk ONU. Ser. Heohrafichni ta heolohichni nauky, 13/6, 50-66.

5. Yermolaev, M.M. (2002). Transformatsiia rodiuchosti solontsevykh gruntiv Lisostepu Ukrainy pid vplyvom melioratsii [Transformation of the soil fertility of the forest-steppe of Ukraine under the influence of reclamation]. Kyiv,-39s.

6. Liubymova, I.N. (2010). Suchasni protsesy hruntoutvorennia v rozoranykh ta melioratyvnykh hruntakh solontsevykh kompleksiv sukhostepovoi zony [Modern processes of soil formation in cultivated and reclamation soils of the solonethic complexes of the dry-steppe zone]. Moscow, Hruntoznavchyi instytut im. V.V.Dokuchaieva: Science, 390-413.

7. Novikova, A.V. (2000). Prohnozuvannia vtorynnoho zasolennia hruntiv pid chas zroshennia [Forecasting of secondary salinization of soils during irrigation]. Urozhai, 166.

8. Semenova-Zabrodyna S. P. (2014). Optymizatsiia solontsiv Prysyvashshia shliakhom perekhodu v boharni umovy [Optimization of solonetz supplements by switching to rainy conditions].Moscow, Nauka, Science, 426-433. 


\section{ДОСЛІДЖЕННЯ ОСОБЛИВОСТЕЙ ТРАНСФОРМАЦІЇ ГРУНТОВОГО ПОКРИВУ ПРИСИВАШШЯ ПІД ВПЛИВОМ ПРИРОДНИХ ТА АНТРОПОГЕННИХ ФАКТОРІВ (НА ПРИКЛАДІ НОВОТРОЇЦЬКОГО РАЙОНУ ТА АЗОВО-СИВАСЬКОГО НАЦІОНАЛЬНОГО ПРИРОДНОГО ПАРКУ)}

Анотація.У статті розглядаються особливості трансформації грунтового покриву Присивашшя на прикладіпорівняльного аналізу трансформації грунтів Новотройцького району та Азово-Сиваського начіонального природного парку під впливом природних та антропогенних факторів.

Грунти Північного Присивашшя, а саме Новотроӥцького району зазнають значних перетворень спричинених антропогенною діяльністю, швидко втрачають свої позитивні властивості при нерачіональному сільськогосподарському використанні.

Довготривале використання трунтів у ріллі $i$, особливо, застосування меліоративних заходів, зумовлюють існування трунтових процесів, які відрізняються від тих, що існують у природних умовах $i$ є на сьогодні маловивченими. В сучасних умовах використання земельних ресурсів необхідна точна інформачія про особливості якісного стану солониевих трунтів для проведення моніторингу та раціонального сільськогосподарського використання, у зв'язку з чим досліджувані питання набувають особливої наукової і практичної значимості.

На основі порівняльного аналізу з'ясовано відмінності між трунтами сільськогосподарського використання та трунтами, які не зазнають антропогенного впливу, тобто знаходяться у природному стані, в межах природоохоронних територій. Доведено, щзо грунти заповідної території у порівнянні з грунтовим покривом Новотроӥцького району, не зазнають значного антропогенного впливу. Територія Новотройцького району 
характеризується значними масштабами розорення сільськогосподарських yzidb.

Ключові слова:Азово-Сиваський національний природний парк ,грунтовий покрив, агроперетворені грунти, меліорація, природні та антропогенні фактори.

$* * * *$

\section{И.С. Полевая, С.В. Фокина}

ИССЛЕДОВАНИЕ ОСОБЕННОСТЕЙ ТРАНСФОРМАЦИИ ПОЧВЕННОГО ПОКРОВА ПРИСИВАШЬЯ ПОД ВОЗДЕЙСТВИЕМ ПРИРОДНЫХ И АНТРОПОГЕННЫХ ФАКТОРОВ (НА ПРИМЕРЕ НОВОТРОИЦКОГО РАЙОНА И АЗОВО-СИВАШСКОГО НАЦИОНАЛЬНОГО ПРИРОДНОГО ПАРКА)

Аннотация. В статье рассматриваются особенности трансформации почвенного покрова Присивашья на примере сравнительного анализа трансформации почв Новотрочикого района и Азово-Сивашского национального природного парка под влиянием природных и антропогенных факторов.

Почвы Северного Присивашья, а именно Новотрочикого района испытывают значительных преобразований вызванных антропогенной деятельностью, быстро теряют свои положительные свойства при нерачиональном сельскохозяйственном использовании.

Длительное использование почв в памне $u$, особенно, применение мелиоративных мероприятий, обусловливают существование почвенных процессов, которые отличаются от тех, что существуют в природных условиях и является на сегодня малоизученными. В современных условиях использования земельных ресурсов необходима точная информация об особенностях качественного состояния солонџовых почв для проведения мониторинга и рационального сельскохозяйственного использования, в связи с чем исследуемые вопросы приобретают особую научную и практическую значимость. 
На основе сравнительного анализа выяснено различия между почвами сельскохозяйственного использования и почвами, не испытывают антропогенного воздействия, то есть находятся в естественном состоянии, в пределах природоохранных территорий. Доказано, что почвы заповедной территории по сравнению с почвенным покровом Новотроицкого района, не подвержень значительному антропогенному воздействию. Территория Новотроицкого района характеризуется значительньми масштабами разорения сельскохозяйственных угодий.

Ключевые слова: Азово-Сивашский национальный природный парк, почвенный покров, агроперетворени почвы, мелиорачия, природные и антропогенные факторы. 